\title{
Efektivitas sistem penyediaan air bersih Perusahaan Daerah Air Minum (PDAM) di kawasan permukiman sekitar Universitas Sebelas Maret, Surakarta
}

\author{
Effectiveness of Municipal Waterworks Water Supply Systems in settlement \\ areas around Universitas Sebelas Maret, Surakarta
}

\author{
M Ulfarina ${ }^{1}$, G Yudana ${ }^{1}$, I Aliyah ${ }^{1}$ \\ ${ }^{1}$ Program Studi Perencanaan Wilayah dan Kota, Fakultas Teknik, Universitas Sebelas \\ Maret
}

Corresponding author's email: murena.ulfarina@gmail.com

\begin{abstract}
Abstrak. Penyediaan air bersih kawasan permukiman sekitar kampus Universitas Sebelas Maret (UNS) Surakarta dilayani oleh Instalasi Pengolahan Air (IPA) Jurug dengan air baku berasal dari Sungai Bengawan Solo. Sistem penyediaan air bersih Perusahaan Daerah Air Minum (PDAM) terdiri dari lima unit yaitu unit air baku, transmisi, produksi, distribusi, dan pelayanan. Pola persebaran permukiman juga memiliki keterkaitan terhadap sistem penyediaan air bersih. Efektivitas sistem penyediaan air terbagi menjadi tiga kategori, yaitu tidak efektif, kurang efektif dan efektif. Data yang digunakan dalam penelitian ini terdiri dari data sekunder yang didapat dari survey data ke PDAM dan BAPPPEDA Surakarta, sedangkan data primer didapat dari wawancara dan kuesioner pelanggan PDAM. Penelitian ini menggunakan metode kuantitatif. Data primer dan sekunder diolah menggunakan teknik analisis skoring, sedangkan pola persebaran permukiman dianalisis menggunakan analisis tetangga tedekat pada software ArcGIS 10.1 kemudian didapatkan pola persebaran permukiman yaitu mengelompok. Pola persebaran permukiman mengelompok mempermudah dalam pendistribusian air bersih. Hasil penelitian ini menyatakan bahwa sistem penyediaan air bersih di kawasan permukiman di sekitar Kampus Kentingan UNS Surakarta kurang efektif namun sudah mendekati efektif.
\end{abstract}

Kata Kunci: Efektivitas; IPA Jurug; Permukiman; Sistem Penyediaan Air

Abstract. Water supply systems in settlement areas around Sebelas Maret University
have served by Water Treatment Plant Jurug with the raw water from Bengawan Solo
river. The water supply of Municipal Waterworks (PDAM) systems consist of 5 units,

Received : November 16, 2018; Accepted: December 2, 2018; Available online: January 30, 2021

Copy right @ 2021, REGION: Jurnal Pembangunan Wilay ah dan Perencanaan Partisipatif 
there are raw water, transmission, production, distribution, and service unit. Settlement pattern also has relevance with water supply systems. The effectiveness of the water supply system is devided into 3 categories: ineffective, less effective, and effective. The data used in this study is secondary data formed by Surakarta's Municipal Waterworks and Regional Development Planning Agency, while the primary data is obtained by interviews and questionnaires for customers. This study used a quantitative method. Primary and secondary data were analyzed by scoring analysis techniques, while the settlement pattern was analyzed using Average Nearest Neighbor analysis on GIS and then categories as a clustered pattern. The clustered settlement pattern makes the distribution of water are easier. The result of this study state that water supply systems in the settlement areas around the UNS Surakarta campus are less effective but have approached an effective level

Keywords: Effectiveness; Settlement; Water Supply System; WTP Jurug System

\section{Pendahuluan}

Kawasan pendidikan di Kota Surakarta menjadi salah satu prioritas pengembangan yaitu meliputi kawasan UNS dan Techno Park yang termasuk dalam SPK (Sub Pusat Pelayanan Kota) Kawasan V. Selain itu Kelurahan Jebres, Jagalan, dan Pucangsawit termasuk dalam PL (Pusat Lingkungan) Kawasan $V$ yang memiliki fungsi sebagai pariwisata, pendidikan tinggi, dan industri kreatif. Kampus UNS yang memiliki aktivitas terpadat adalah kampus pusat yang terdapat di Kentingan karena merupakan kampus induk UNS. Di sekitar kawasan pendidikan mengalami peningkatan kebutuhan ruang untuk permukiman serta sarana prasarana penunjangnya [1]. Salah satu prasarana yang sangat berhubungan dengan keberlangsungan kehidupan manusia adalah air bersih. Peningkatan jumlah penduduk mengakibatkan adanya peningkatan kebutuhan air bersih. Sumur di Kota Surakarta pada tahun 2015 sebanyak $80 \%$ mengalami pencemaran bakteri Eschericia Coli. Kelurahan Jebres termasuk dalam zona merah atau sangat tinggi tingkat pencemarannya. Bakteri tersebut mencemari sumur dan sumber air dangkal yang dikonsumsi warga. Hampir seluruh sungai di Kota Surakarta juga tercemari oleh bakteri tersebut [2]. Padahal Sungai Bengawan Solo menjadi salah satu pemasok sumber air untuk memenuhi kebutuhan air bersih di Kawasan Timur Surakarta dan kawasan UNS pada khususnya.

Efektivitas berhubungan dengan pencapaian tujuan dan kunci kesuksesan suatu organisasi, efektivitas sistem harus ditunjang dengan kualitas layanan sistem [3]. Kualitas layanan akan mempengaruhi tingkat kepuasan dari pengguna suara prasarana. Dalam penyediaan air bersih terdapat 2 jenis jaringan yaitu jaringan perpipaan dan jaringan non perpipaan. Sistem Penyediaan Air Bersih terdiri dari 5 unit yaitu unit air baku, unit transmisi, unit produksi, unit distribusi, dan unit pelayanan [4]. Masing-masing unit dalam sistem penyediaan air bersih saling terkait dan saling berpengaruh terhadap unit lainya. Dalam pendistribusian air bersih di kawasan permukiman sekeliling Kampus Kentingan UNS juga dipengaruhi oleh pola permukiman. Menurut Petter Hagget terdapat 3 pola yaitu seragam (uniform), acak (random), mengelompok (clustered) [5]. Perhitungan pola persebaran permukiman dapat 
dilakukan menggunakan software ArcGIS 10.1 yang kemudian akan didapatkan nilai T apabila menggunakan Average Nearest Neighbor Analysis.

Kawasan permukiman di sekitar Kampus UNS dilayani oleh 1 IPA, yaitu Instalasi Pengolahan Air Jurug yang terdapat di Kelurahan Jebres yang memanfaatkan air baku dari Sungai Bengawan Solo. Berdasarkan impresi awal ditemukan beberapa rumah yang memiliki kualitas air bersih yang kurang, seperti air berwarna kecoklatan dan air tidak mengalir pada jam-jam tertentu. Tujuan penelitian ini yaitu untuk mengetahui efektivitas sistem penyediaan air bersih PDAM di kawasan permukiman sekitar kampus UNS Surakarta dan sebagai bahan masukan kepada PDAM Kota Surakarta dalam penyediaan jaringan air bersih dan bahan pertimbangan penyediaan prasarana dalam SPPIP serta dokumen terkait lainnya.

\section{Metode}

Pendekatan penelitian yang digunakan yaitu pendekatan deduktif dengan metode penelitian kuantitatif. Pengumpulan data dilakukan melalui survey sekunder ke beberapa instansi pemerintahan terkait, sedangkan survey primer didapat melalui kuesioner kepada responden yaitu pelanggan PDAM kategori rumah tangga (SR). Teknik sampling yang digunakan yaitu menggunakan rumus Slovin pada pelanggan PDAM kategori rumah tangga. Sampel dalam penelitian ini yaitu 98 sampel. Data yang didapat kemudian di kompilasi dan dianalisis. Teknik analisis yang digunakan yaitu analisis skoring dan analisis tetangga terdekat untuk analisis pola persebaran permukiman. Penjelasan lebih lanjut akan dijelaskan dalam kerangka analisis dalam Gambar 1.

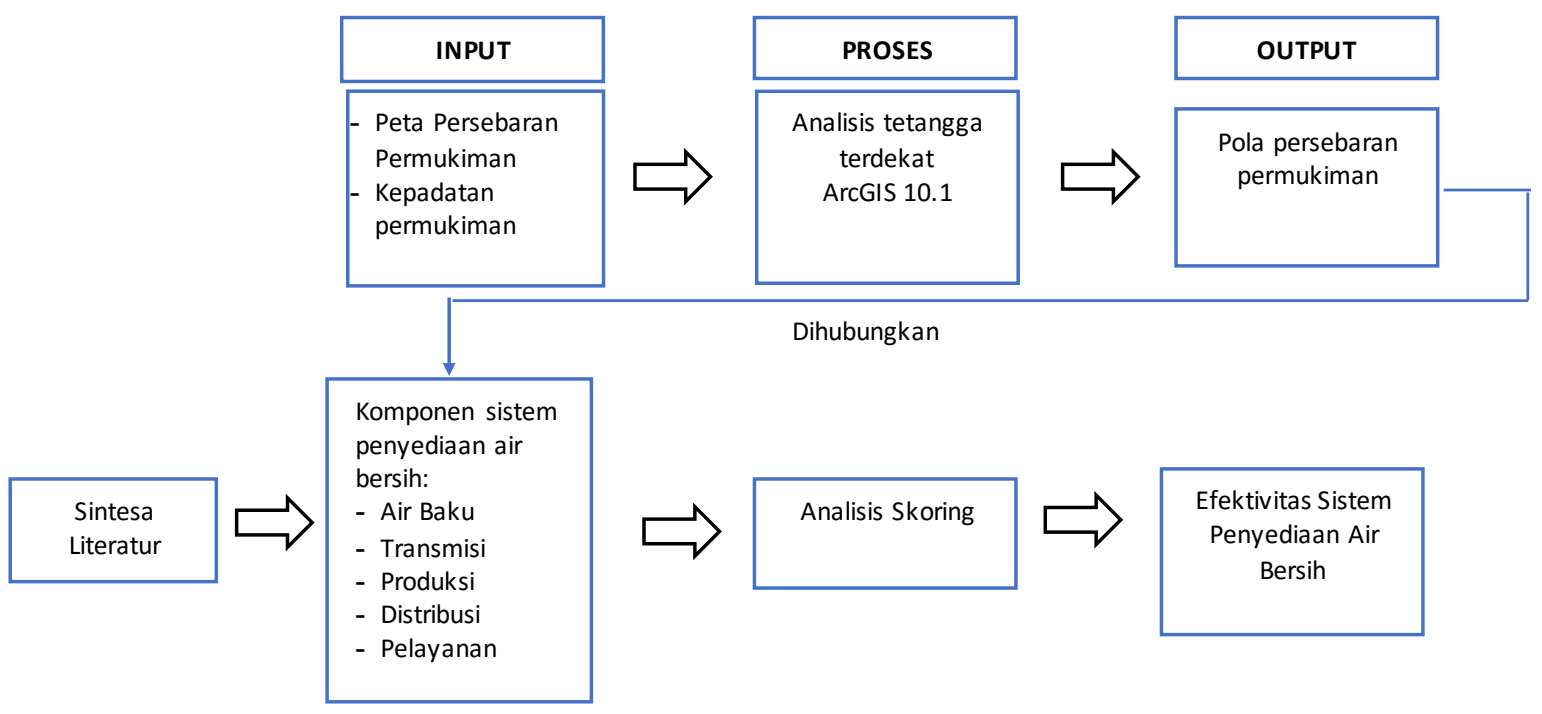

Gambar 1. Kerangka analisis penelitian.

Kriteria penilaian sistem penyediaan air bersih PDAM dapat dilihan pada Tabel 1. 
Tabel 1. Indikator efektivitas sistem penyediaan air bersih PDAM [6-13].

\begin{tabular}{|c|c|c|c|c|c|}
\hline \multirow{2}{*}{ Variabel } & \multirow{2}{*}{ Sub Variabel } & \multicolumn{3}{|c|}{ Indikator } & \multirow[t]{2}{*}{ Sumber } \\
\hline & & Skor 1 & Skor 2 & Skor 3 & \\
\hline \multicolumn{6}{|c|}{ Ketercapaian Tujuan Penyediaan Air Bersih } \\
\hline Unit Air & Kapa sitas Air & Kapasitas air & Kapasitas air baku & Kapasitas air baku & {$[6,7]$} \\
\hline \multirow[t]{3}{*}{ Baku } & Baku & $\begin{array}{l}\text { baku sama } \\
\text { dengan } \\
\text { kebutuhan rata- } \\
\text { rata air bersih }\end{array}$ & $\begin{array}{l}130 \% \text { dari } \\
\text { kebutuhan rata- } \\
\text { rata air bersih }\end{array}$ & $\begin{array}{l}>130 \% \text { dan kel ebihan } \\
\text { air dapat dijadikan } \\
\text { cadangan }\end{array}$ & \\
\hline & $\begin{array}{l}\text { Kontinuitas } \\
\text { Air Baku }\end{array}$ & $\begin{array}{l}\text { Debitair selalu } \\
\text { berkurang }\end{array}$ & $\begin{array}{l}\text { Debit air } \\
\text { berkurang hanya } \\
\text { pada bulan } \\
\text { tertentu }\end{array}$ & $\begin{array}{l}\text { Debit air tetap } \\
\text { sepanjang tahun }\end{array}$ & [7] \\
\hline & $\begin{array}{l}\text { Kualitas Air } \\
\text { Baku }\end{array}$ & $\begin{array}{l}\text { Tidak diuji di } \\
\text { laboratorium } \\
\text { secata rutin }\end{array}$ & $\begin{array}{l}\text { Telah diujisecara } \\
\text { rutin } \\
\text { dan tingkat } \\
\text { pencemaran } \\
\text { rendah-sedang }\end{array}$ & $\begin{array}{l}\text { Telah diujisecara rutin } \\
\text { dan tidakterjadi } \\
\text { pencemaran air }\end{array}$ & [7] \\
\hline $\begin{array}{l}\text { Unit } \\
\text { Transmisi }\end{array}$ & $\begin{array}{l}\text { Pengaliran Air } \\
\text { Baku }\end{array}$ & $\begin{array}{l}\text { - Stasiun pompa } \\
\text { terl etak di } \\
\text { daerah banjir } \\
\text { - Tidak mudah } \\
\text { dijangkau }\end{array}$ & $\begin{array}{l}\text { Stasiun pompa } \\
\text { terl etak di el evasi } \\
\text { paling atas dari } \\
\text { pengalaman } \\
\text { waktu banjir, } \\
\text { mudah dijangkau, } \\
\text { dan jalur pipa } \\
\text { sependek } \\
\text { mungkin }\end{array}$ & $\begin{array}{l}\text {-Tidak terletak di } \\
\text { daerah banjir } \\
\text {-Mudah dijangkau } \\
\text {-Menghindari jalur } \\
\text { yang mengakibatkan } \\
\text { konstruksi sulit dan } \\
\text { mahal } \\
\text {-Jalur pipa sependek } \\
\text { mungkin }\end{array}$ & [8] \\
\hline \multirow[t]{2}{*}{$\begin{array}{l}\text { Unit } \\
\text { Produksi }\end{array}$} & $\begin{array}{l}\text { Produktivitas } \\
\text { Pemanfaatan } \\
\text { Instalasi } \\
\text { Produksi }\end{array}$ & $\begin{array}{l}\text { Produktifitas } \\
\text { pemanfaatan } \\
\text { instalasi produksi } \\
<50 \%\end{array}$ & $\begin{array}{l}\text { Produktifitas } \\
\text { pemanfaatan } \\
\text { instalasi produksi } \\
50-<70 \%\end{array}$ & $\begin{array}{l}\text { Produktifitas } \\
\text { pemanfaatan instalasi } \\
\text { produksi } 70-90 \%\end{array}$ & [9] \\
\hline & $\begin{array}{l}\text { Bangunan } \\
\text { Pengolahan } \\
\text { Air Baku }\end{array}$ & $\begin{array}{l}\text { Kurang dari } 6 \\
\text { unit pada proses } \\
\text { pengolahan air }\end{array}$ & $\begin{array}{l}\text { Dilengkapi } \\
\text { dengan } 6 \text { unit } \\
\text { pada proses } \\
\text { pengolahan air }\end{array}$ & $\begin{array}{l}\text { - Dilengkapi dengan } 6 \\
\text { unit pada proses } \\
\text { pengolahan air dan } \\
\text { kondisi baik } \\
\text { - Dilengkapi sarana } \\
\text { pengolahan lumpur } \\
\text { sisa hasil pengolahan } \\
\text { air baku dan } \\
\text { berfungsi dengan baik }\end{array}$ & {$[7,10]$} \\
\hline \multirow[t]{2}{*}{$\begin{array}{l}\text { Unit } \\
\text { Distribusi }\end{array}$} & $\begin{array}{l}\text { Sarana } \\
\text { Pengaliran Air } \\
\text { Bersih }\end{array}$ & $\begin{array}{l}\text { - Ters edia sistem } \\
\text { pemompaan } \\
\text { dan kondisi } \\
\text { kurang baik } \\
\text { - Ters edia pipa } \\
\text { induk saja } \\
\text { - Menggunakan } \\
\text { sistem cabang }\end{array}$ & $\begin{array}{l}\text { - Tersedia sistem } \\
\text { pemompaan } \\
\text { dan kondisi baik } \\
\text { - Tersedia pipa } \\
\text { induk dan } \\
\text { distribusi } \\
\text { - Mengguna-kan } \\
\text { sistem } \\
\text { melingkar }\end{array}$ & $\begin{array}{l}\text {-Menggunakan } \\
\text { percampuransistem } \\
\text { pemompaandan } \\
\text { gravitasi dan } \\
\text { kondisinya baik } \\
\text {-Tersedia pipa distribusi } \\
\text { dan pipa induk } \\
\text {-Menggunakan sistem } \\
\text { grid }\end{array}$ & {$[7,11]$} \\
\hline & Reservoir & Tidak tersedia & Ters edia reservoir & - Reservoir penyeimbang & [8] \\
\hline
\end{tabular}

Received : November 16, 2018; Accepted: December 2, 2018; Available online: January 30, 2021

Copy right $\odot$ 2021, REGION: Jurnal Pembangunan Wilay ah dan Perencanaan Partisipatif 


\begin{tabular}{|c|c|c|c|c|c|}
\hline \multirow{7}{*}{ Variabel } & \multirow{2}{*}{ Sub Variabel } & \multicolumn{3}{|c|}{ Indikator } & \multirow[t]{2}{*}{ Sumber } \\
\hline & & Skor 1 & Skor 2 & Skor 3 & \\
\hline & & $\begin{array}{l}\text { reservoir } \\
\text { penyeimbang } \\
\text { dan pelayanan }\end{array}$ & $\begin{array}{l}\text { penyeimbang } \\
\text { terl etak di dekat } \\
\text { instalasi } \\
\text { pengola han air/ } \\
\text { Tersedia reservoir } \\
\text { pelayanan }\end{array}$ & $\begin{array}{l}\text { terletak di dekat } \\
\text { instalasi pengolahan air } \\
\text { dan kondisi baik } \\
\text { - Reservoir pelayanan } \\
\text { berada di dekat lokasi } \\
\text { pusat da erah } \\
\text { pelayanan dan masing- } \\
\text { masing zona dilengkapi } \\
1 \text { reservoir apabila } \\
\text { elevasi muka tanah } \\
\text { wilayah pelayanan } \\
\text { bervariasi }\end{array}$ & \\
\hline & $\begin{array}{l}\text { Kualitas Air } \\
\text { Bersih }\end{array}$ & $\begin{array}{l}\text { Kondisi air } \\
\text { keruh/ berbau/ } \\
\text { berwarna/ atau } \\
\text { berasa }\end{array}$ & $\begin{array}{l}\text { Air tidak keruh, } \\
\text { berbau, } \\
\text { berwarna,atau } \\
\text { berasa dan Air } \\
\text { teruji } \\
\text { laboratorium } \\
\text { namun tidak } \\
\text { berkala }\end{array}$ & $\begin{array}{l}\text { - Air tidak keruh, } \\
\text { berbau, berwarna,atau } \\
\text { berasa } \\
\text { - Air telah diuji di } \\
\text { laboratorium secara } \\
\text { rutin }\end{array}$ & {$[6]$} \\
\hline & $\begin{array}{l}\text { Kontinuitas } \\
\text { Air Bersih }\end{array}$ & $\begin{array}{l}\text { Air mengalir> } \\
\text { 16jam/hari }\end{array}$ & $\begin{array}{l}\text { Air mengalir16- } \\
18 \mathrm{jam} / \mathrm{hari}\end{array}$ & $\begin{array}{l}\text { Air dapat mengalir } \\
\text { selama }<18-24 \text { jam/hari }\end{array}$ & [12] \\
\hline & $\begin{array}{l}\text { Tingkat } \\
\text { Kehilangan Air }\end{array}$ & $\begin{array}{l}\text { Tingkat } \\
\text { kehilangan air }> \\
40 \%->60 \%\end{array}$ & $\begin{array}{l}\text { Tingkat } \\
\text { kehilanganair } \leq \\
20 \%-\leq 40 \%\end{array}$ & $\begin{array}{l}\text { Tingkat kehilangan air } \\
<20 \%\end{array}$ & {$[9,13]$} \\
\hline & $\begin{array}{l}\text { Konsumsi Air } \\
\text { Bersih }\end{array}$ & $\begin{array}{l}\text { Konsumsi air < } \\
90 \\
\text { liter/orang/hari }\end{array}$ & $\begin{array}{l}\text { Konsumsi air } \\
\text { antara 90-100 } \\
\text { liter/orang/hari }\end{array}$ & $\begin{array}{l}\text { Konsumsi Air > } 100 \\
\text { liter/orang/hari }\end{array}$ & [9] \\
\hline $\begin{array}{l}\text { Unit } \\
\text { Pelayanan }\end{array}$ & $\begin{array}{l}\text { Cakupan } \\
\text { Pelayanan }\end{array}$ & $\begin{array}{l}\text { Cakupan } \\
\text { pelayananair } \\
\text { bersih }<60 \%\end{array}$ & $\begin{array}{l}\text { Cakupan } \\
\text { pelayananair } \\
\text { bersih } \\
60 \%-80 \% \\
\end{array}$ & $\begin{array}{l}\text { Cakupan pelayananair } \\
\text { bersih }>80 \%\end{array}$ & [7] \\
\hline \multicolumn{6}{|c|}{ Kualitas Pelayanan Air Bersih } \\
\hline Unit & Kualitas Air & Kepuasan & Kepuasan & Kepuasan Pelanggan & Peneliti, \\
\hline \multirow[t]{3}{*}{ Distribusi } & Bersih & $\begin{array}{l}\text { Pelanggan PDAM } \\
\text { terhadap } \\
\text { Kulaitas Air } \\
\text { Bersih rendah }\end{array}$ & $\begin{array}{l}\text { Pelanggan PDAM } \\
\text { terhadap Kualitas } \\
\text { Air Bersih sedang }\end{array}$ & $\begin{array}{l}\text { PDAM terhadap } \\
\text { Kulaitas Air Bersih } \\
\text { tinggi }\end{array}$ & 2018 \\
\hline & Kontinuitas & Kepuasan & Kepuasan & Kepuasan Pelanggan & Peneliti, \\
\hline & Air Bersih & $\begin{array}{l}\text { Pelanggan PDAM } \\
\text { terhadap } \\
\text { Konti uitas Air } \\
\text { Bersih rendah }\end{array}$ & $\begin{array}{l}\text { Pelanggan PDAM } \\
\text { terhadap } \\
\text { Kontinuitas Air } \\
\text { Bersih sedang }\end{array}$ & $\begin{array}{l}\text { PDAM terhadap } \\
\text { Kontinuitas Air Bersih } \\
\text { tinggi }\end{array}$ & 2018 \\
\hline
\end{tabular}

\section{Hasil dan pembahasan}

Hasil penelitian dan pembahasan akan dibahas mengenai air baku, transmisi, produksi, distribusi dan pelayanan air bersih, kemudian akan dirangkum menjadi satu yaitu kategori efektivitas sistem penyediaan air bersih di kawasan penelitian. 


\subsection{Identifikasi persebaran penduduk}

Penggunaan lahan di Kelurahan Jagalan, Jebres, dan Pucangsawit mayoritas digunakan sebagai permukiman. Berikut ini tabel luas wilayah dan jumlah unit rumah di Kelurahan Jagalan, Jebres, dan Pucangsawit tahun 2016 dalam Tabel 2.

Tabel 2. Tingkat kepadatan permukiman di kawasan penelitian (Unit / Km2) [14].

\begin{tabular}{lcccc}
\hline \multicolumn{1}{c}{ Kelurahan } & $\begin{array}{c}\text { Jumlah Rumah } \\
\text { (Unit) }\end{array}$ & Luas Wilayah $\left(\mathbf{K m}^{2}\right)$ & Tingkat Kepadatan & $\begin{array}{c}\text { Kepadatan } \\
\text { (rumah/Ha) }\end{array}$ \\
\hline Jagalan & 2664 & 0,65 & 4.098 & 41 \\
Pucangsawit & 1727 & 1,27 & 1.360 & 14 \\
Jebres & 3563 & 3,17 & 1.124 & 11 \\
\hline
\end{tabular}

Berdasarakan kriteria kepadatan permukiman, Kelurahan Jagalan merupakan kawasan yang memiliki kepadatan permukiman sedang, sedangkan Kelurahan Jagalan dan Jebres termasuk dalam kategori kepadatan permukiman rendah. Kelurahan Jebres menjadi kelurahan dengan kepadatan terendah dikarenakan pada Kelurahan Jebres terdapat banyak guna lahan selain permukiman yang memiliki luas yang besar, seperti UNS, RS Moewardi, Kampus ISI Surakarta, Taman Satwa Taru (TSTJ) Jurug. Sedangkan Kelurahan Kelurahan Jagalan memang hampir semua kawasanya digunakan sebagai lahan permukiman.

Selain kepadatan bangunan permukiman, dalam penelitian ini juga terdapat kepadatan penduduk bruto terhadap lahan permukiman. Kepadatan penduduk brutto yang akan dihitung yaitu kepadatan penduduk berdasarkan luasan lahan permukiman di kawasan penelitian, berikut dapat dilihat pada Tabel 3.

Tabel 3. Tingkat kepadatan penduduk brutto terhadap luas permukiman [14].

\begin{tabular}{lccccc}
\hline Kelurahan & $\begin{array}{c}\text { Jumlah } \\
\text { Penduduk }\end{array}$ & $\begin{array}{c}\text { Luas Permukiman } \\
\mathbf{( H a )}\end{array}$ & $\begin{array}{c}\text { Tingkat } \\
\text { Kepadatan }\end{array}$ & $\begin{array}{c}\text { Jumlah } \\
\text { Rumah }\end{array}$ & $\begin{array}{c}\text { Jumlah } \\
\text { Pelanggan } \\
\text { PDAM (SR) }\end{array}$ \\
\hline Jagalan & 12.194 & 57,27 & 212,92 & 2.664 & 1.056 \\
Pucangsawit & 13.822 & 45,41 & 304,38 & 1.727 & 1.427 \\
Jebres & 33.076 & 114,89 & 287,89 & 3.563 & 3.396 \\
\hline
\end{tabular}

Berdasarkan kepadatan penduduk bruto terhadap lahan permukiman di atas diketahui bahwa Kelurahan Jagalan memiliki kepadatan penduduk terendah dibandingkan dua kelurahan lainnya, sedangkan Kelurahan Pucangsawit merupakan kelurahan dengan kepadatan penduduk bruto tertinggi di kawasan penelitian. Kepadatan permukiman serta kepadatan penduduk bruto memiliki hasil yang berbeda. Berdasarkan data di atas juga diketahui bahwa apabila dilihat dari perbandingan jumlah rumah dan jumlah pelanggan PDAM, Kelurahan Jebres memiliki perbandingan terendah yaitu se kitar 39\%, Kelurahan Jagalan memiliki perbandingan sekitar $82 \%$, sedangkan Kelurahan Jebres memiliki perbandingan hampir 95\% rumah di Kelurahan Jebres menggunakan air PDAM. Hal ini sesuai dengan teori menurut Pranoto [15] bahwa suplai air paling banyak yaitu suplai air ke Kelurahan Jebres karena Kelurahan Jebres memiliki jumlah pelanggan PDAM terbanyak. Peta persebaran permukiman dapat dilihat pada Gambar 2. 


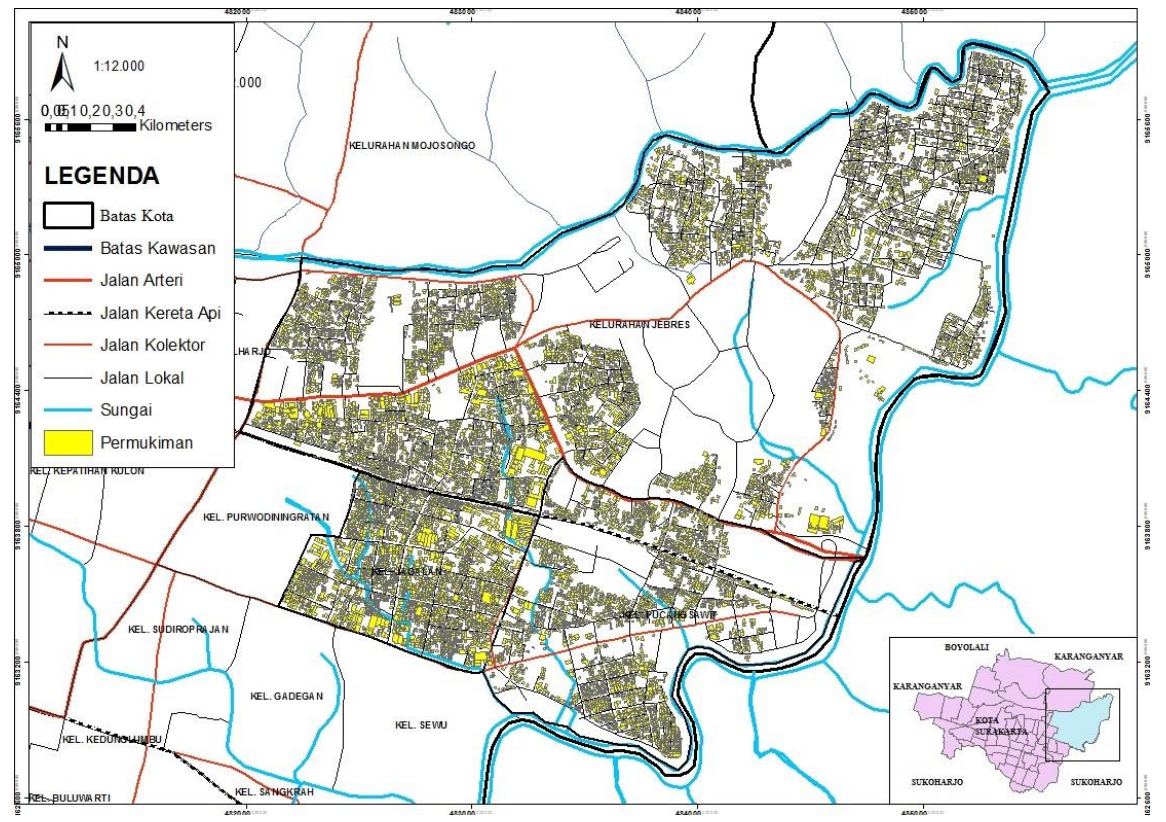

Gambar 2. Persebaran permukiman di kawasan penelitian.

Untuk mengetahui jenis pola persebaran permukiman di kawasan penelitian dapat diketahui menggunakan analisis tetangga terdekat menggunakan software Arcgis 10.1, kemudian di dapat hasil T yaitu 0,69774. Sehingga berdasarkan teori dari Hagget kawasan permukiman di sekitar Kampus UNS dikategorikan sebagai pola mengelompok karena nilai T yang didapat kurang dari 1 [16]. Sehingga sesuai dengan teori dari Pelambi, Sonny, dan Michael bahwa pola persebaran permukiman mengelompok mempermudah distribusi air bersih [17].

\subsection{Efektivitas sistem penyediaan air bersih}

3.2.1 Ketercapaian tujuan penyediaan air bersih. Dalam ketercapaian tujuan penyediaan air bersih akan lima variabel yaitu unit air baku, transmisi, produksi, distribusi, dan pelayanan akan dibahas dan dianalsis menggunakan teknik analisis skoring berdasarkan teori dan standar yang ada.

\subsubsection{Unit air baku}

a) Kapasitas air baku

Berdasarkan hasil wawancara diketahui bahwa air baku yang digunakan sebagai di kawasan penelitian bersumber dari tiga buah sumber air, yaitu air Sungai Bengawan Solo dengan kapasitas 100 liter/detik dan dua sumur dalam yaitu sumur dalam (SD) Jurug I dan II dengan kapasitas 10 dan 15 liter/detik. Kebutuhan air bersih terdiri dari kebutuhan dosmestik, niaga kecil dan besar, fasilitas umum fasilias sosial, serta adanya kebocoran air. Pe njelasanya dapat dilihat pada Tabel 4.

Tabel 4. Kebutuhan air bersih kawasan penelitian.

\begin{tabular}{lcccccccc}
\hline Kelurahan & $\begin{array}{c}\text { Jumlah } \\
\text { Penduduk }\end{array}$ & $\begin{array}{c}\text { Kebutuhan } \\
\text { Domestik }\end{array}$ & $\begin{array}{c}\text { Niaga } \\
\text { Kecil }\end{array}$ & $\begin{array}{c}\text { Niaga } \\
\text { Besar }\end{array}$ & $\begin{array}{c}\text { Fasilitas } \\
\text { Umum }\end{array}$ & $\begin{array}{c}\text { Fasilitas } \\
\text { Sosial }\end{array}$ & Kebocoran & Jumlah \\
\hline Jagalan & 16.980 & 1.698 .000 & 51.300 & 5000 & 254700 & 84900 & 339600 & 2.433 .500 \\
Jebres & 5.280 & 528.000 & 279.900 & 50000 & 79200 & 26400 & 105600 & 1.069 .100 \\
\hline
\end{tabular}

Received : November 16, 2018; Accepted: December 2, 2018; Available online: January 30, 2021 


\begin{tabular}{lcccccccc}
\hline Kelurahan & $\begin{array}{c}\text { Jumlah } \\
\text { Penduduk }\end{array}$ & $\begin{array}{c}\text { Kebutuhan } \\
\text { Domestik }\end{array}$ & $\begin{array}{c}\text { Niaga } \\
\text { Kecil }\end{array}$ & $\begin{array}{c}\text { Niaga } \\
\text { Besar }\end{array}$ & $\begin{array}{c}\text { Fasilitas } \\
\text { Umum }\end{array}$ & $\begin{array}{c}\text { Fasilitas } \\
\text { Sosial }\end{array}$ & Kebocoran & Jumlah \\
\hline $\begin{array}{l}\text { Pucangsawit } \\
\text { Jumlah Kebutuhan Total }\end{array}$ & 7135 & 713.500 & 90.900 & 35000 & 107025 & 35675 & 142700 & 1.124 .800 \\
& & & & & & & $\mathbf{4 . 6 2 7 . 4 0 0}$ \\
\hline
\end{tabular}

Berdasarkan tabel di atas dapat diasumsikan bahwa Kelurahan Jebres, Jagalan, dan Pucangsawit memiliki $71,14 \%$ dari seluruh pelanggan PDAM yang bersumber dari IPA Jurug atau dengan kapasitas sekitar 88,92 liter/detik (didapat dari 71,14\% dikalikan dengan kapasitas IPA Jurug yakni 125 liter/detik). Kebutuhan air total untuk Kelurahan Jagalan, Jebres, dan Pucangsawit yaitu 4.627.400 liter/hari atau sekitar 53,55 liter/detik. Kapasitas air baku di IPA jurug yaitu 88,92 liter/detik. Berdasarkan perhitungan sebelumnya, kapasitas air baku di kawasan perencanaan mendapat skor 3 apabila mecapai 130\% dari kebutuhan air bersih atau 69,62 liter/detik sehingga sub variabel kapasitas air baku mendapat skor 3. Hal ini dapat disimpulkan bahwa kapasitas air baku mecukupi karena lebih besar dari pada kebutuhan air bersih di kawasan penelitian sehingga sesuai dengan teori Asghara [7].

b) Kontinuitas air baku

Sub variabel kontinuitas air baku didapat dari instrumen survey berupa wawancara kepada petugas IPA Jurug. Debit Sungai Bengawan Solo pada tahun 2010-2015 dapat dilihat pada Tabel 5.

Tabel 5. Debit sungai Bengawan Solo selama tahun 2010-2015 (dalam m3) [18].

\begin{tabular}{lcccccrrrrrrr}
\hline & Jan & Feb & \multicolumn{1}{c}{ Mar } & \multicolumn{1}{c}{ Apr } & \multicolumn{1}{c}{ Mei } & \multicolumn{1}{c}{ Jun } & \multicolumn{1}{c}{ Jul } & \multicolumn{1}{c}{ Ags } & \multicolumn{1}{c}{ Sep } & \multicolumn{1}{c}{ Okt } & \multicolumn{1}{c}{ Nop } & Des \\
\hline Max & 585,28 & 536,69 & 253,10 & 276,83 & 532,41 & 161,37 & 58,38 & 26,05 & 142,09 & 158,62 & 195,20 & 266,25 \\
Rerata & 335,66 & 300,29 & 201,70 & 202,68 & 186,63 & 65,32 & 30,52 & 17,03 & 32,15 & 35,21 & 65,13 & 156,45 \\
Min & 146,73 & 170,96 & 112,23 & 95,24 & 39,71 & 3,18 & 9,42 & 3,00 & 2,00 & 2,00 & 25,00 & 84,00 \\
\hline
\end{tabular}

Berdasarkan data di atas dapat diketahui bahwa debit air Sungai Bengawan Solo fluktuatif tergantung musim, saat musim hujan air akan lebih banyak daripada saat musim kemarau. Namun berdasarkan hasil wawancara diketahui bahwa meskipun debit air fluktuatif, begitu pula dengan air yang diambil juga fluktuatif tergantung musim. Air yang diambil dapat lebih dari 100 liter/detik maupun kurang. Sehingga hal ini kurang sesuai dengan pernyataan Asghara [7] karena debit air berkurang pada bulan tertentu/fluktuatif sehingga skor kontinuitas air baku yaitu 2 .

c) Kualitas air baku

Air Sungai Bengawan Solo secara rutin dilakukan pemeriksaan laboratorium untuk mengetahui kualitas air. Selain diuji di dilaboratorim juga sering dilakukan pemeriksaan oleh petugas. Sulit untuk menemukan sungai di Pulau Jawa yang yang tidak mengalami pencemaran. Menurut Wismabrata [19] Sungai Bengawan Solo yang mengalami pencemaran dengan kadar sedang tetapi masih dapat diolah menjadi air bersih namun harus dengan pengecekan secara rutin. Diduga polutan logam berat berasal dari industri dan Tempat Pembuangan Akhir (TPA). Hal ini kurang sesuai dengan pernyataan Asghara [7]. Sehingga berdasarkan penjabaran tersebut maka kualitas air baku mendapatkan skor 2 . 


\subsubsection{Unit transmisi}

a) Pengaliran air baku

Pengaliran sistem transmisi pada sistem jaringan air bersih berfungsi untuk mengalirkan air baku menuju ke bagian produksi. Air baku dialirkan dengan pipa yang menghubungkan dari alat pengambil air yang terdapat di dalam Sungai Bengawan Solo menuju ke bagian produksi dengan bantuan sistem pemompaan sesuai dengan teori dari Peavy, Donald, dan George karena sesuai dengan kondisi topografi masing-masing IPA (Instalasi Pengolahan Air) [20]. IPA Jurug terdapat di tepi Sungai Bengawan Solo sehingga jalur pipa transmisi tergolong pendek. IPA Jurug terletak di daerah banjir, selain itu IPA Jurug pernah terendam banjir beberapa tahun lalu karena air Sungai Bengawan Solo yang meluap. Namun sangat jarang terjadi banjir di sekitar IPA Jurug. Letak IPA Jurug mudah dijangkau, letaknya berada di belakang rusun Jurug dan mudah diakses karena dekat dengan jalan raya. Dalam hal jalur pipa sudah sesuai dengan standar dari SNI 7508 Tahun 2011 [8], namun letak yang tidak berada pada elevasi banjir belum sesuai dengan standar sehingga mendapatkan skor 2 .

\subsubsection{Unit produksi}

a) Produktivitas pemanfaatan instalasi produksi

Berdasarkan hasil wawancara pengolahan air baku dari Bengawan Solo diolah melalui proses di atas dan berkurang antara $2-10 \%$ untuk proses pembersihan instalasi pengolahan air. Produktivitas pemanfaatan instalasi produksi bergantung pada kapasitas produksi dan kapasitas terpasang. Kapasitas produksi IPA Jurug yakni 100 liter/detik sesuai dengan anjuran dari PSDA, sedangkan kapasitas produksi di IPA Jurug yakni 70-80 liter/detik yang berasal dari Sungai Bengawan Solo. Sehingga berdasarkan data tersebut dapat diketahui bahwa produktivitas instalasi produksi sekitar 70-80\%, sesuai dengan Kepmendagri Nomor 47 Tahun 1999 dalam Hartono [9]. Sehingga mendapatkan skor 3 karena standarnya yaitu 70-90\%. Produktivitas instalasi produksi dapat dihitung menggunakan kapasitas produksi dan kapasitas terpasang, sehingga kedua hal tersebut dapat dimaksimalkan lagi dalam penangangannya.

\section{b) Bangunan pengolahan air baku}

IPA Jurug memiliki enam unit proses pengolahan air yaitu unit pra-sedimentasi, koagulasi, flokulasi, sedimentasi, filtrasi, dan desinfeksi sesuai dengan SNI 7831 Tahun 2012 dan dikategorikan dalam kondisi baik karena adanya perawatan dan pemantauan [10]. Apabila terjadi kerusakan segera dilakukan perbaikan atau penggantian. IPA Jurug dilengkapi dengan sarana pengolahan lumpur sisa atau Sludge Drying Bed (SDB), namun karena terjadi kerusakan pompa maka kolam pengolahan lumpur tidak dapat dimanfaatkan sehingga hasil pengolahan air sehingga langsung dibuang ke badan sungai. Sehingga kurang sesuai dengan SNI Nomor 6774 Tahun 2008 [12]. Karena tidak difungsikan sehingga mencemari lingkungan sehingga mendapakan skor 2 .

\subsubsection{Unit distribusi}

a) Sarana pengaliran air bersih

Berdasarkan hasil wawancara diketahui bahwa debit air yang keluar yaitu sebesar 30 liter/detik dengan menggunakan pipa 6 inch dengan bantuan pompa air bertegangan $45 \mathrm{KW}$. 
Air tersebut mengalir ke kawasan Kentingan, Ngoresan, dan Gulon dan kawasan Jebres lainnya. Sedangkan debit air 70 liter/detik menggunakan pipa 8 inch dengan bantuan pompa air bertegangan $90 \mathrm{KW}$ yang mengalirkan air menuju ke Jagalan dan Pucangsawit. Sumur dalam di makam pahlawan Pucangsawit hanya mengalirkan air ke sebagian Kelurahan Pucangsawit. Jaringan distribusi air bersih di kawasan penelitian dapat dilihat pada Gambar 3.

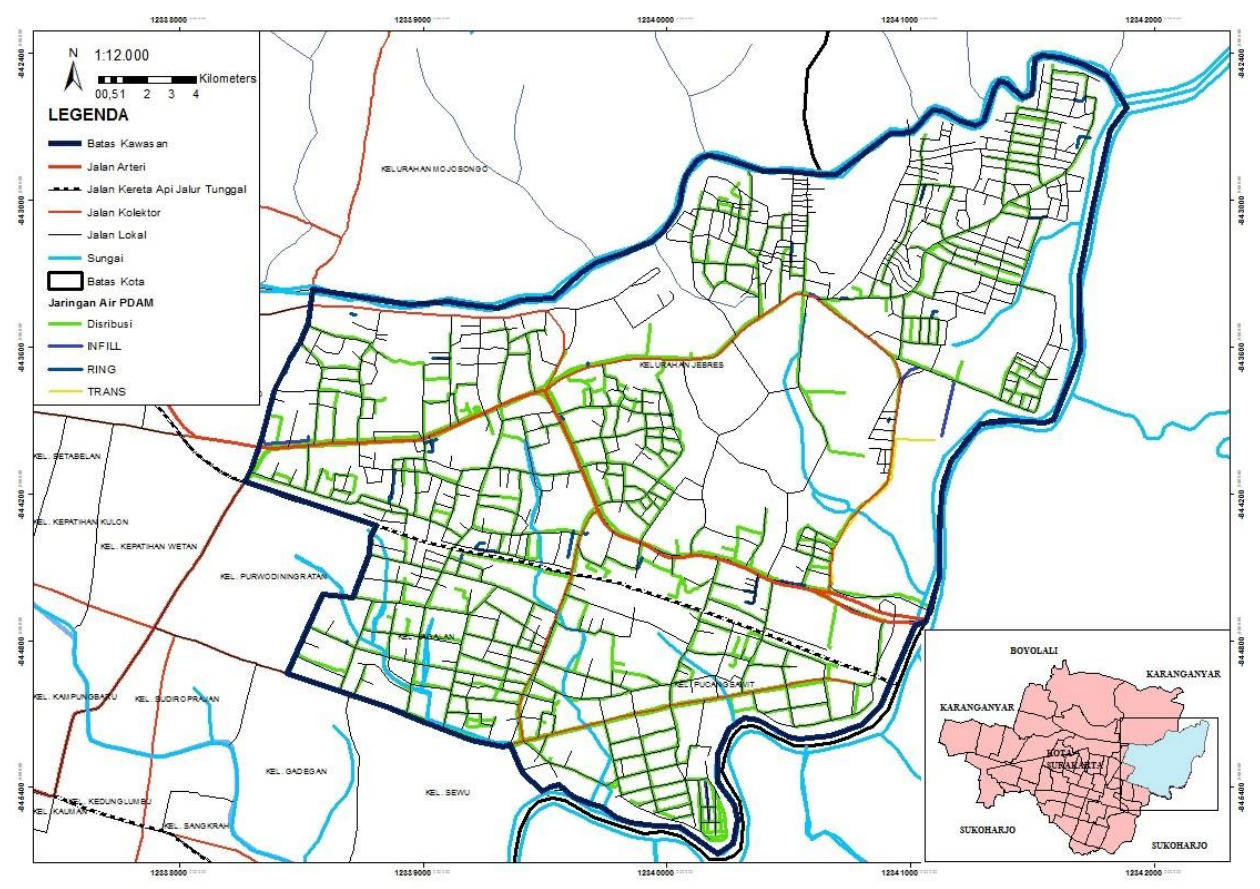

Gambar 3. Jaringan distribusi air bersih PDAM.

Berdasarkan peta tersebut dapat diketahui bahwa jaringan air bersih PDAM di kawasan permukiman sekitar Kampus UNS Surakarta menggunakan sistem loop (melingkar), pipa jaringan mengikuti jaringan jalan. Hal ini kurang sesuai dengan teori Al-Layla karena sistem grid lebih menguntungkan [11]. Jaringan utama atau pipa induk hanya tersebar di sekitar jalan utama dan jalan besar, sedangkan untuk jalan kampung dan sambungan ke rumahrumah menggunakan pipa yang lebih kecil. Permukiman yang berada pada tengah-tengah kumpulan permukiman akan kesulitan sehingga menyulitkan proses distribusi. Berdasarkan penjelasan di atas dapat diketahui bahwa air bersih yang sudah diolah didistribusikan menggunakan sistem pemompaan karena tidak dimungkinkan menggunakan sistem gravitasi sehingga kurang sesuai dengan pendapat Asghara [7]. Kondisi pemompaan baik, selain itu pengaliran air juga menggunakan pipa induk dan pipa distribusi untuk sampai ke rumah pelanggan air bersih. Berdasarkan uraian tersebut sarana pengaliran air bersih mendapatkan skor 2.

\section{b) Reservoir}

Setelah air bersih selesai di olah, air selanjutkan akan disimpan dalam reservoir sebelum akhirnya didistribusikan kepada penduduk. Reservoir distribusi terletak di IPA Jurug dan kondisi baik serta berumur \pm 5 tahunan. Volume reservoir di IPA Jurug yaitu $500 \mathrm{~m} 3$. Jumlah 
reservoir yaitu 1 sedangkan sedangkan standarnya terdapat 2 reservoir. Daerah pelayanan memiliki elevasi yang beragam sehingga reservoir pelayanan yang hanya berjumlah 1 masih kurang karena di beberapa tempat dengan elevasi muka tanah yang lebih tinggi dari IPA Jurug sering mengalami permasalahan air yang mati pada jam-jam tertentu sehingga belum sesuai dengan SNI 7508 Tahun 2011 [8]. Sehingga didapatkan skor 2.

c) Kualitas air bersih

Data kualitas air bersih didapat dengan menggunakan kuesioner, kualitas air bersih yang ideal yaitu air yang tidak berbau, berasa, dan berwarna. Sebanyak 54 responden atau 55,1\% menyatakan kondisi air kurang baik, sedangkan 44 responden atau 44,89\% menyatakan kualitas air baik. Sehingga persentase 55,1\% dikalikan dengan skor indikator 1 sehingga dihasilkan skor 0,55. Selanjutnya persentase 44,89\% dikalikan dengan skor indikator 3 sehingga didapat skor 1,34. Kedua skor tersebut digabungkan menjadi skor akhir yaitu 1,89. Narasumber yang menyatakan kualitas air kurang baik dikarenakan air yang mengalir dirumah mereka kualitasnya kadang kurang baik, air kadang berwarna kecoklatan, kadang kekuningan, agak keruh, dan kadang mengandung kadar kaporit yang lebih banyak dari biasanya sehingga kurang sesuai dengan teori dari Apriyana [6] dan Agustina [21].

d) Kontinuitas air bersih

Data kontinuitas air bersih didapat dengan menggunakan kuesioner. Sebanyak 13 responden atau $13,27 \%$ menyatakan air mengalir $16-18$ jam/hari, sebanyak 85 responden atau $86,73 \%$ menyatakan air mengalir 18-24 jam/hari. Persentase 13,27\% dikalikan dengan skor indikator 2 didapatkan hasil 0,26. Selanjutnya persentase $86,73 \%$ dikalikan dengan skor indikator 3 didapatkan hasil 2,60. Kemudian kedua skor dijumlahkan untuk mendapatkan skor akhir yaitu 2,86. Narasumber mengatakan air selalu mengalir namun juga banyak yang mengatakan bahwa pada jam-jam tertentu air sering tidak mengalir. Berdasarkan hasil kuesioner diketahui bahwa dalam jam-jam tertentu terutama jam sibuk banyak rumah yang debitnya kecil atau tidak menyala sama sekali. Jam sibuk yaitu jam berangkat sekolah/kantor antara jam 6-8 pagi, jam makan siang yaitu jam 12- jam 1 siang, dan jam pulang kantor antara jam 4 - jam 5 sore, sehingga diasumsikan jam sibuk dalam sehari adalah 6 jam. Namun mayoritas penduduk menyatakan aliran air selalu dapat menyala setiap saat sehingga sesuai dengan standar dari Direktorat Jenderal Cipta Karya Departemen Pekerjaan Umum [4].

\section{e) Tingkat kehilangan air bersih}

Tingkat kehilangan atau kebocoran air yang dimaksud yaitu kebocoran air pada distribusi, kebocoran air di kawasan penelitian dapat terjadi karena beberapa sebab, menurut PDAM penyebabnya antara lain yaitu: water meter pelanggan rusak, instalasi distribusi rusak berat/ jaringan sudah tua, tekanan air tidak merata, administrasi/ kesalahan pencatatan meter. Kawasan penelitian termasuk bagian dari Kota Surakarta sehingga tingkat kehilangan air di kawasan penelitian diasumsikan sama dengan Kota Surakarta yaitu 44,95\% sehingga belum sesuai dengan standar menurut PP Nomor 16 Tahun 2005 [13]. Skor tingkat kehilangan air yang didapatkan yaitu 1. 
f) Konsumsi air bersih

Konsumsi air bersih di kawasan penelitian dilihat berdasarkan pemakaian air bersih oleh pelanggan PDAM. Konsumsi air bersih setiap pelanggan PDAM akan berbeda. Kawasan penelitian yang berada di Kota Surakarta maka menggunakan standar kebutuhan 100 liter/orang/hari. Terdapat 98 responden dengan 497 anggota keluarga didapatkan rata-rata pemakaian air perbulan yaitu $2.111 \mathrm{m3} /$ bulan. Berdasarkan data tersebut dapat diketahui rata-rata pemakaian air perhari yaitu dengan membagi pemakaian air perbulan dengan jumlah jiwa sehingga didapatkan hasil 141,5 liter/hari sesuai dengan teori dari Hartono [9]. Konsumsi air bersih di kawasan permukiman sekitar kampus UNS Surakarta yaitu sekitar 141,5 liter/orang/hari, dan sambungan rumah yang sudah terlayani yaitu 5.859 unit dengan 29.295 jiwa yang terlayani maka kebutuhan air untuk sambungan rumah yaitu 47,97 liter/detik, sedangkan kapasitas Instalasi Pengolahan Air (IPA) Jurug yaitu 125 liter/detik. Dikarenakan pelanggan sambungan rumah merupakan kategori pelanggan terbesar maka IPA Jurug dapat memenuhi kebutuhan air bersih di kawasan penelitian sehingga sudah sesuai dengan teori dari Joko [22]. Skor Konsumsi air bersih yang didapatkan yaitu 3.

\subsubsection{Unit pelayanan}

a) Cakupan pelayanan

Cakupan pelayanan dalam sub variabel ini akan diberdaskan pelanggan PDAM yang akan dibandingkan dengan penduduk total/KK total di kawasan penelitian. Berdasarakan Kecamatan Jebres dalam Angka tahun 2017 diketahui bahwa jumlah rumah di kawasan penelitian yaitu 7.954, sedangkan jumlah pelanggan PDAM yaitu sebanyak 5.879 [14]. Sehingga cakupan pelayanan air bersih PDAM nya yaitu dengan membagi jumlah pelanggan PDAM dengan jumlah $\mathrm{KK} / \mathrm{jumlah}$ rumah sehingga dihasilkan yang terlayani PDAM yaitu 73,91 \%. Sehingga kurang sesuai dengan pendapat dari Asghara [7] serta target pencapaian yang diharapkan Kementerian Pekerjaan Umum dan Perumahan Rakyat. Kemudian dilakukan perhitungan untuk menentukan skor sehingga didapat hasil skor 2.

\subsubsection{Kualitas pelayanan air bersih}

\subsubsection{Distribusi air bersih}

a) Kualitas air

Kepuasan pelanggan terhadap kualitas air didapat dari kuesioner terhadap pelanggan PDAM di kawasan penelitian. Sebanyak 21 responden atau 21,4\% menyatakan kepuasan terhadap kualitas air rendah. Sebanyak 49 responden atau $50 \%$ menyatakan kepuasan terhadap kualitas air sedang. Sedangkan sisanya yaitu 28 responden atau $28,6 \%$ menyatakan kepuasan terhadap kualitas air tinggi. Persentase $21,4 \%$ dikalikan dengan skor 1 didapat skor yaitu 0,21 , selanjutnya persentase $50 \%$ dikalikan dengan skor 2 didapat nilai skor 1 . Kemudian persentase $28,6 \%$ dikalikan dengan skor indikator 3 didapatkan hasil 0,86. Terakhir skor diakumulasikan untuk mendapatkan skor untuk sub variabel kualitas air be rsih yaitu 2,07.

b) Kontinuitas air

Kepuasan pelanggan terhadap kontinuitas air didapat dari kuesioner terhadap pelanggan PDAM di kawasan penelitian. Sebanyak 5 responden atau 5,1\% menyatakan kepuasan terhadap kontinuitas air rendah. Sebanyak 14 responden atau $14,29 \%$ menyatakan kepuasan 
terhadap kontinuitas air sedang. Sedangkan sisanya yaitu 79 responden atau 80,61\% menyatakan kepuasan terhadap kontinuitas air tinggi. Persentase 5,1 \% dikalikan dengan skor 1 didapat skor yaitu 0,051, selanjutnya persentase 14,29\% dikalikan dengan skor 2 didapat nilai skor 0,28. Kemudian persentase $80,61 \%$ dikalikan dengan skor indikator 3 didapatkan hasil 2,42. Terakhir skor diakumulasikan untuk mendapatkan skor untuk sub variabel kualitas air bersih yaitu 2,75 .

Setelah dilakukan analisis maka jumlah skor diakumulasi untuk mengetahui kategori efektivitas sistem penyediaan air bersihnya, dapat dilihat pada Tabel 6.

Tabel 6. Akumulasi skor analisis skoring.

\begin{tabular}{llc}
\hline \multicolumn{1}{c}{ Variabel } & \multicolumn{1}{c}{ Sub Variabel } & Skor \\
\hline \multirow{3}{*}{ Air Baku } & Ketercapaian Tujuan & \\
& Kapasitas Air Baku & $\mathbf{3}$ \\
& Kontinuitas Air Baku & $\mathbf{2}$ \\
Transmisi & Kualitas Air Ba ku & $\mathbf{2}$ \\
Produksi & Pengaliran Air Baku & $\mathbf{2}$ \\
& Produktivitas Instalasi Produksi & $\mathbf{3}$ \\
Distribusi & Bangunan Pengolahan Air Baku & $\mathbf{2}$ \\
& Sarana Pengaliran Air Bersih & $\mathbf{2}$ \\
& Reservoir & $\mathbf{2}$ \\
& Kualitas Air Bersih & $\mathbf{1 , 8 9}$ \\
& Kontinuitas Air Bersih & $\mathbf{2 , 8 6}$ \\
& Tingkat Kehilangan Air & $\mathbf{1}$ \\
Pelayanan & Konsumsi Air Bersih & $\mathbf{3}$ \\
& Cakupan Pelayanan & $\mathbf{2}$ \\
Distribusi & Kualitas Pelayanan & $\mathbf{2 , 0 7}$ \\
& Kualitas Pelayanan Air Bersih & $\mathbf{2 , 7 5}$ \\
JUMLAH & Kontinuitas Pelayanan Air Bersih & $\mathbf{3 3 , 5 7}$ \\
\hline
\end{tabular}

Setelah masing-masing variabel dianalisis menggunakan indikator-indiakator di atas maka skor akhir dijumlahkan untuk mengetahui kategori efektivitas sistem penyediaan air bersihnya, menggunakan rumus interval untuk mengetahui interval setiap kelas, dengan jumlah kelas yaitu tiga didapat kategori seperti pada Tabel 7.

Tabel 7. Kategori tingkat efektivitas sistem penyediaan air bersih PDAM.

\begin{tabular}{cc}
\hline Tingkat Efektivitas & Jumlah Skor \\
\hline Efektif & $\geq 35$ \\
Kurang Efektif & $\geq 25-<34,99$ \\
Tidak Efektif & $<24,99$ \\
\hline
\end{tabular}

Berdasarkan tabel kategori di atas maka sistem penyediaan air bersih di kawasan permukiman sekitar Kampus UNS Surakarta termasuk dalam kategori kurang efektif, namun sudah mendekati efektif dengan selisih skor yaitu 1,43 untuk mencapai kategori efektif. 


\section{Kesimpulan}

Permukiman di sekitar kampus UNS Surakarta memiliki pola persebaran permukiman mengelompok dengan tingkat kepadatan permukiman rendah hingga sedang. Sistem penyediaan air bersih perpipaan terdiri dari lima unit/komponen yaitu unit air baku, transmisi, produksi, distribusi, dan pelayanan. Masing-masing komponen tersebut masih memiliki sub variabel. Dari hasil penelitian dapat disimpulkan bahwa sistem penyediaan air bersih PDAM/perpipaan di kawasan permukiman sekitar kampus UNS Surakarta termasuk kurang efektif namun mendekati efektif. Unit air baku termasuk dalam kategori efektif karena komponennya cukup sesuai dengan standar dan teori [7, 8, 9, 10, 17]. Skor tertinggi yaitu skor kapasitas air baku, berbeda dengan unit transmisi termasuk dalam kategori kurang efektif. Pada unit produksi berdasarkan analisis termasuk dalam kategori efektif dengan skor tertinggi yaitu produktivitas instalasi produksi. Unit distribusi termasuk kurang efektif karena beberapa komponennya memiliki skor yang rendah yakni kualitas air bersih dan tingkat kehilangan air. Sedangkan pada unit pelayanan termasuk dalam kategori kurang efektif karena belum mampu mencapai target yang ditentukan. Pada kepuasan pelanggan terhadap kualitas air bersih didapat hasil yaitu sedang/kurang efektif, sedangkan pada kepuasan pelanggan terhadap kontinuitas air bersih didapat hasil yaitu tinggi/ efektif.

\section{Referensi}

[1] Yuliastuti N dan Fatchurochman A 2012 Pengaruh Perkembangan Lahan Terbangun terhadap Kualitas Lingkungan Permukiman (Studi Kasus: Kawasan Pendidikan Kelurahan Tembalang) Jurnal Presipitasi 901 pp 10-6 DOI: 10.14710/presipitasi.v9i1.10-16

[2] Sunaryo A 2015 Bahaya, 80 Persen Sumur Warga di Solo Tercemar Bakteri E-coli Merdeka.com Diakses melalui https://www.merdeka.com/peristiwa/bahaya-80persen-sumur-warga-di-solo-tercemar-bakteri-e-

coli.html\#: :text=Merdeka.com\%20\%2D\%2080\%20Persen\%20air,coli\%20(E\%2Dcoli) .\&text=\%22Akibatnya\%20banyak\%20bakteri\%20yang\%20meresap,Rabu\%20(28\%2F 1)

[3] Rewah J dan Rotikan R 2016 Analisa Efektivitas Sistem Informasi di Kantor Badan Kepegawaian dan Diklat Kota Manado Cogito Smart Journal 22 pp 180-93 Diakses dari http://cogito.unklab.ac.id/index.php/cogito/article/view/28

[4] Direktorat Jenderal Cipta Karya Departemen Pekerjaan Umum 2007 Rencana Program Invesatasi Jangka Menengah Bidang PU/Cipta Karya Diakses dari http://ciptakarya.pu.go.id/dok/rpijm/01.\%20PENJELASAN\%20UMUM\%2017-092007.pdf

[5] Saraswati D A, Subiyanto S, dan Wijaya A P 2016 Analisis Perubahan Luas dan Pola Persebaran Permukiman (Studi Kasus: Kecamatan Tembalang, Kecamatan Banyumanik, Kecamatan Gunungpati, Kecamatan Mijen Kota Semarang Jawa Tengah) Jurnal Geodesi Undip 5 1 pp 155-63 Diakses dari https://ejournal3.undip.ac.id/index.php/geodesi/article/view/10577

[6] Apriyana P 2010 Evaluasi Kinerja Pelayanan Air Bersih Komunal di Wilayah Pengembangan Ujung Berung Kota Bandung Jurnal Perencanaan Wilayah dan Kota 
$21 \quad 2 \quad$ pp $\quad 95-110 \quad$ Diakses dari http://journals.itb.ac.id/index.php/jpwk/article/view/4155/2238

[7] Asghara A 2007 Strategi Peningkatan Kapasitas Pelayanan Air Bersih di Kota Bangko Kabupaten Merangin Tesis (Semarang: Universitas Diponegoro) Diakses dari http://eprints.undip.ac.id/16528/

[8] SNI Nomor 7508 Tahun 2011 tentang Tata Cara Penentuan Jenis Unit Instalasi Pengolahan Air Berdasarkan Sumber Air Baku Diakses dari http://nawasis.org/portal/digilib/read/sni-7508-2011-tata-cara-penentuan-jenisunit-instalasi-pengolahan-air-berdasarkan-sumber-air-baku/51429

[9] Hartono D 2005 Alternatif Pemenuhan Air Bersih oleh PDAM di Kota Semarang Tesis (Semarang: Universitas Diponegoro) Diakses dari http://eprints.undip.ac.id/14650/

[10] SNI Nomor 7831 Tahun 2012 tentang Perencanaan Sistem Penyediaan Air Minum. Diakses dari http://nawasis.org/portal/digilib/read/sni-7831-2012-perencanaansistem-penyediaan-airminum/51424\#: :text=Standar\%20perencanaan\%20sistem\%20penyediaan\%20air,u nit\%20distribusi\%2C\%20dan\%20unit\%20pelayanan

[11] Al-Layla M A, Ahmad S, dan Middlebrooks E J 1977 Water Supply Engineering Design (Michigan: Ann Arbor Science)

[12] SNI Nomor 6774 Tahun 2008 tentang Tata Cara Perencanaan Unit Paket Instalasi Pengolahan Air Diakses dari http://nawasis.org/portal/digilib/read/sni-6774-2008tata-cara-perencanaan-unit-paket-instalasi-pengolahan-air/51431

[13] Peraturan Pemerintah Nomor 16 Tahun 2005 tentang Pengembangan Sistem Penyediaan Air Minum Diakses dari https://peraturan.bpk.go.id/Home/Details/49357

[14] Badan Pusat Statistik 2018 Kecamatan Jebres Dalam Angka 2017 Diakses dari https://surakartakota.bps.go.id/publication/2018/01/03/27dd8c7fed05a0ec9ba620 9e/kecamatan-jebres-dalam-angka-2017.html

[15] Pranoto A B 2007 Hubungan Kepadatan Permukiman dengan Ketersediaan Infrastruktur Tesis (Semarang: Universitas Diponegoro) Diakses dari https://core.ac.uk/download/pdf/11716244.pdf

[16] Muta'ali L 2015 Teknik Analisis Regional untuk Perencanaan WIlayah, Tata Ruang dan Lingkungan (Yogyakarta: Badan Penerbit Fakultas Geografi Universitas Gadjah Mada)

[17] Pelambi M R, Tilaar S, dan Rengkung M M 2016 Identifikasi Pola Sebaran Permukiman Terencana di Kota Manado Jurnal Spasial: Perencanaan Wilayah dan Kota 31 pp 5565 Diakses dari https://ejournal.unsrat.ac.id/index.php/spasial/article/view/11651

[18] Dinas PUSDATARU Provinsi Jawa Tengah 2017 Data Debit Sungai Bengawan Solo Jurug Rerata Bulanan (m3/det) Tahun 2010-2015 [Internet] PUSDATARU Open Source Provinsi Jawa Tengah Diakses dari https://pusdataru.jatengprov.go.id/data/data_group=debit-sungai/page-1_kab-surakarta-dbt_Sg-20102015.html

[19] Wismabrata M H 2018 Limbah Pabrik Ancam Ekosistem Sungai Bengawan Solo, Ini Kata Ahli Kompas.com Diakses dari https://sains.kompas.com/read/2018/03/10/113154223/limbah-pabrik-ancamekosistem-sungai-bengawan-solo-ini-kata-ahli 
[20] Peavy H S, Donald R R, dan George T 1985 Environmental Engineering (New York: McGraw-Hill)

[21] Agustina D V 2007 Analisa Kinerja Sistem Distribusi Air Bersih PDAM Kecamatan Banyumanik di Perumnas Banyumanik (Studi Kasus Perumnas Banyumanik Kel. Srondol Wetan) Tesis (Semarang: Universitas Diponegoro) Diakses dari http://eprints.undip.ac.id/15472/1/Dian_Vita_Agustina.pdf

[22] Joko T 2010 Unit Air Baku dalam Sistem Penyediaan Air Minum (Yogyakarta: Graha IImu) 